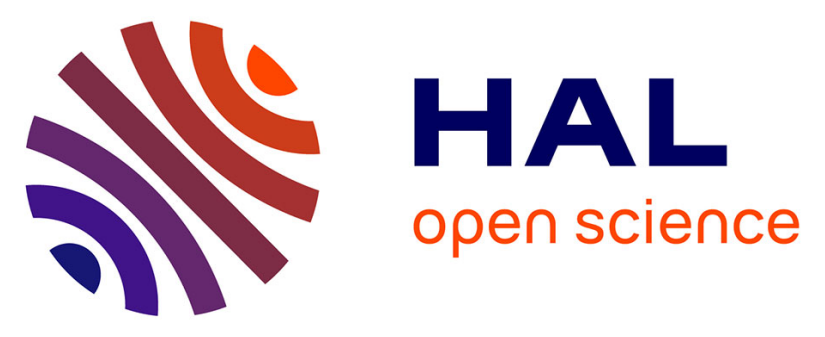

\title{
Cerebral atrophy is linked to clinical severity and worsens with aging in patients with Pelizaeus-Merzbacher disease and Spastic Paraplegia type 2
}

Catherine Sarret, Jean-Jacques Lemaire, Anna Sontheimer, Jerome Coste, Bruno Pereira, Fabien Feschet, Basile Roche, Jean-Pierre Renou, Odile Boespflug-Tanguy

\section{To cite this version:}

Catherine Sarret, Jean-Jacques Lemaire, Anna Sontheimer, Jerome Coste, Bruno Pereira, et al.. Cerebral atrophy is linked to clinical severity and worsens with aging in patients with Pelizaeus-Merzbacher disease and Spastic Paraplegia type 2. 42nd Congress of the European Society of Neurological Pediatry, in conjunction with the 20th Mediterranean Meeting of Child Neurology, European Society of Neurological Pediatry, Sep 2014, Montpellier, France. pp.90, 10.1016/j.ijdevneu.2015.04.245 . hal01870933

\section{HAL Id: hal-01870933 https://hal.science/hal-01870933}

Submitted on 8 Nov 2018

HAL is a multi-disciplinary open access archive for the deposit and dissemination of scientific research documents, whether they are published or not. The documents may come from teaching and research institutions in France or abroad, or from public or private research centers.
L'archive ouverte pluridisciplinaire HAL, est destinée au dépôt et à la diffusion de documents scientifiques de niveau recherche, publiés ou non, émanant des établissements d'enseignement et de recherche français ou étrangers, des laboratoires publics ou privés. 


\title{
Cerebral atrophy is linked to clinical severity and worsens with aging in patients with Pelizaeus-Merzbacher disease and Spastic Paraplegia type 2
}

\author{
Sarret C. ${ }^{1}$, Lemaire J.-J. ${ }^{1}$, Sontheimer A. ${ }^{1}$, Coste J. ${ }^{1}$, Pereira B. ${ }^{1}$, Feschet F. ${ }^{1}$, \\ Roche B. ${ }^{1}$, Renou J.-P. ${ }^{2}$, Boespflug-Tanguy O. ${ }^{3}$
}

1. IGCNC - Université d'Auvergne, France

2. INRA Saint Genès-Champanelle, France

3. Hôpital Robert Debré, Paris, France

Objective: This study aims to determine the natural history of genetic hypomyelinating disorders Pelizaeus-Merzbacher disease (PMD) and Spastic Paraplegia type 2 (SPG2) on magnetic resonance imaging (MRI) and to correlate $\mathrm{MRI}$ results with clinical severity.

Methods: A prospective study in 35 patients with variable forms of PMD or SPG2 was performed on a total of 66 cerebral MRI. A myelination score and a global atrophy score were determined for each MRI. We also performed image segmentation to calculate corpus callosum area, cerebellum, white matter and gray matter volumes.

Results: Multivariate analysis with adjustment to the age revealed a significant difference for global atrophy score and corpus callosum area in different subgroups of severity at the first MRI acquisition. Evolution of MRI over time showed an increasing score of myelination until the age of 12 years, followed by stabilization. On the contrary, global atrophy, atrophy of corpus callosum and cerebellum worsened in the majority of patients with aging. No change in gray matter and white matter proportions was noticed over time.

Discussion: This study points out a correlation between cerebral atrophy and clinical severity in patients with PMD and SPG2 whereas degree of myelination was not clearly discriminating. It also highlighted, for the first time in a large cohort of patients, a clear inter- and intra-individual cerebral atrophy over time involving white and gray matter. 